Vol. 1 No. 1, Feb 2021, hlm. 25 - 30

DOI: https://doi.org/10.33330/.v1i1.1019

Available online at http://jurnal.stmikroyal.ac.id/index.php/jutsi

\title{
PERANCANGAN POMPA ANGIN MINI DENGAN MEMANFAATKAN PANEL SURYA BERBASIS ARDUINO
}

\author{
Agung Prabowo ${ }^{1}$, Nofriadi $^{2 *}$, Sudarmin $^{3}$ \\ ${ }^{1}$ Mahasiswa Prodi Sistem Komputer, STMIK Royal \\ ${ }^{2}$ Prodi Sistem Komputer, STMIK Royal \\ ${ }^{3}$ Prodi Sistem Informasi, STMIK Royal \\ *email: nofriadi.royal85@yahoo.com
}

\begin{abstract}
Motorbikes are vehicles owned by almost everyone, especially inIndonesia. But the number of motorbikes is not matched by the presence of a workshop, especially a tire repair shop. When a motorbike rider experiences a flat tire he must push the motorbike for long distance. This research is designed to help motorbike rider who experience a flat tire, so they no longer need to push a motorcycle. The tool design work system to be made is to use an Arduino nano controller because of its small and affordable size. 2pcs 1 watt solar panel which functions to charge the 22.2VDC battery which is used to run the tool designed. The MPX5700AP pressure sensor is a sensor for reading motorcycle tire pressure which will be displayed on the LCD that has been set on the nano Arduino. Then the user only needs to enter motorcycle tire pressure with the KPA unit with the provided keypad, and the pump will automatically fill the tires according to the user's wishes. This tool is designed with a descriptive research method, and with this tool is expected to help motorbike rider who often driver long distances or rural motorbike rider who experience flat tire problems.
\end{abstract}

Keywords:solar cell, automatic pump, keypad 4x4, dc pump, MPX5700AP

\begin{abstract}
Abstrak:Sepeda motor merupakan kendaraan yang dimiliki hampir seluruh masyarakat, terutama di Indonesia. Namun dengan banyaknya sepeda motor, tidak di imbangi dengan keberadaan bengkel, terutama bengkel tambal ban. Sehingga ketika pengendara sepeda motor mengalami kempes ban harus mendorong sepeda motornya dalam jarak yang cukup jauh. Penelitian ini dibuat untuk membantu pengendara sepeda motor yang mengalami ban kempes, sehingga tidak perlu lagi untuk mendorong sepeda motor. Sistem kerja dari rancangan alat yang akan dibuat adalah menggunakan kontroler arduino nano karena berukuran kecil dan harga terjangkau. 2 Panel surya 1watt yang berfungsi untuk mengisi daya baterai 22.2VDC yang digunakan untuk menjalankan alat yang dirancang. Sensor tekanan MPX5700AP sebagai sensor untuk membaca tekanan angin ban sepeda motor yang akan ditampilkan ke LCD yang sudah di setting pada ardunio nano. Lalu pengguna hanya perlu memasukkan tekanan angin ban sepeda motor dengan satuan KPA dengan keypad yang sudah disediakan, dan pompa akan secara otomatis mengisi angin ban sesuai dengan keinginan dari pengguna. Alat ini diharapkan dapat membantu pengendara sepeda motor yang sering berkendara jarak jauh ataupun pengendara sepeda motor di pedalaman desa yang mengalami kendala ban kempes.
\end{abstract}

Kata kunci:panel surya, pompa otomatis, keypad 4x4, pompa dc, MPX5700DP 
Vol. 1 No. 1, Feb 2021, hlm. 25 - 30

DOI: https://doi.org/10.33330/.v1i1.1019

Available online at http://jurnal.stmikroyal.ac.id/index.php/jutsi

\section{PENDAHULUAN}

Pada saat ini, sepeda motor merupakan kendaraan yang dimiliki oleh hampir seluruh masyarakat, terutama di Indonesia. Terlebih lagi banyak dealer sepeda motor yang memberikan diskon untuk para konsumen sehingga setiap tahunnya penjualan sepeda motor khususnya di Indonesia selalu meningkat, namun dengan meningkatnya pengguna sepeda motor tidak diimbangi dengan keberadaan bengkel tambal ban di daerah pedalaman atau dalam perjalanan jauh. Peran pompa angin sangat diperlukan pengendara sepeda motor [1][2]. Walaupun banyak pompa angin yang dijual dipasaran banyak juga pengendara sepeda motor yang tidak berminat membelinya ataupun membawanya, dikarenakan pompa angin yang dijual sulit untuk dibawa dan juga penggunaannya banyak memakan energi. Sudah ada beberapa penelitian yang membahas tentang pompa dan juga panel surya.

Pompa yang menggunakan sumber daya matahari saat ini sudah banyak di gunakan terutama di daerah terpencil [3]. Dalam menjalani kehidupan kita sebagai makhluk hidup tidak bisa terlepas dari air. Maka dari itu untuk mendapatkan air kita membutuhkan sebuah pompa yang hidup dengan arus listrik dari PLN. Terkadang PLN juga tidak bisa mensuply kebutuhan masyarakat, maka dari itu untuk ,menghidupkan sebuah pompa air di butuhkan arus listrik dari sumber yang lain yaitu arus listrik dari cahaya matahari [4][5].

Kendaraan roda dua saat ini merupakan kendaraan yang paling banyak di minati oleh masyarakat. Hal ini di karenakan harga yang yang tidak terlalu mahal [6]. Dalam hal berkendaraa menggunakan roda dua, tekanan angina ban kendaraan harus di perhatikan supaya tidak terjadi kecelakaan [7][8].

\section{METODE}

Dalam melakukan penelitian ini penulis membuat kerangka kerja dengan tujuan supaya lebih memudahkan peneliti dalam melaksnakan penelitian ini. Adapun kerangka kerja adalah: (1) Pengamatan Lapangan, menentukan judul dan mendapati masalah yang ada., (2)Pencarian literature, untuk menyelesaikan permasalahan yang selama ini dialami pengguna sepeda motor yang mengalami kempes ban saat perjalanan jauh atau sedang berada di pelosok desa., (3) Pemesanan alat, pompa angin dc, sensor MPX5700AP, Modul USB IC TP4506, LCD 20x4., (4) Pengujian modul, pengujian pompa angin dc, pengujian sensor tekanan angin ban MPX5700AP, pengujian modul usb IC TP4506, pengujian menampilkan informasi LCD 20x4., (6) Pengujian alat, pengujian mengisi angin ban sepeda motor yang kempes., (7) Impelementasi, diuji coba di lapangan, di saat pengguna motor mengalami kendala ban kempes ketika sedang melakukan perjalanan jauh atau sedang berada di pelosok desa. 
Vol. 1 No. 1, Feb 2021, hlm. 25 - 30

DOI: https://doi.org/10.33330/.v1i1.1019

Available online at http://jurnal.stmikroyal.ac.id/index.php/jutsi

\section{HASIL DAN PEMBAHASAN}

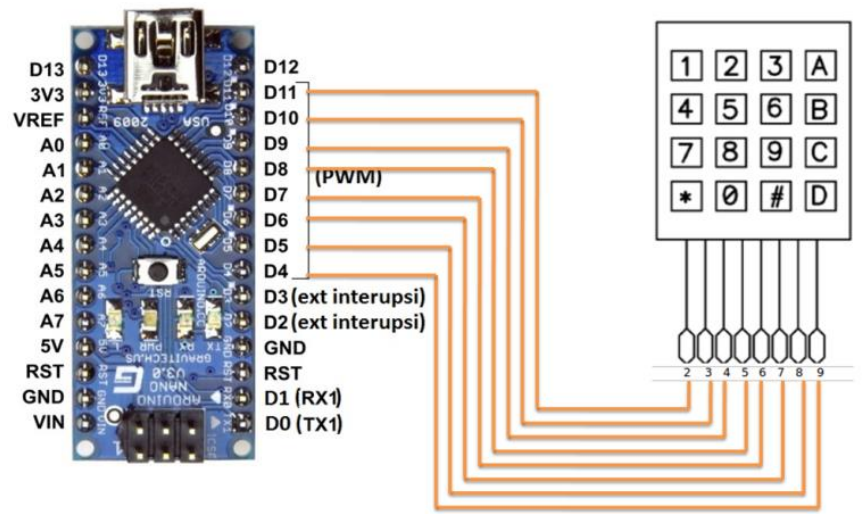

Gambar 1. Keypad dan Arduino

Pada gambar 1 keypad di gunakan adalah keypad 4x4 sebagai tempat mengetikan berapa tekanan angin untuk sepeda motor yang akan di berikan. Board arduino berfungsi sebagai pusat kendali dari system yang di buat

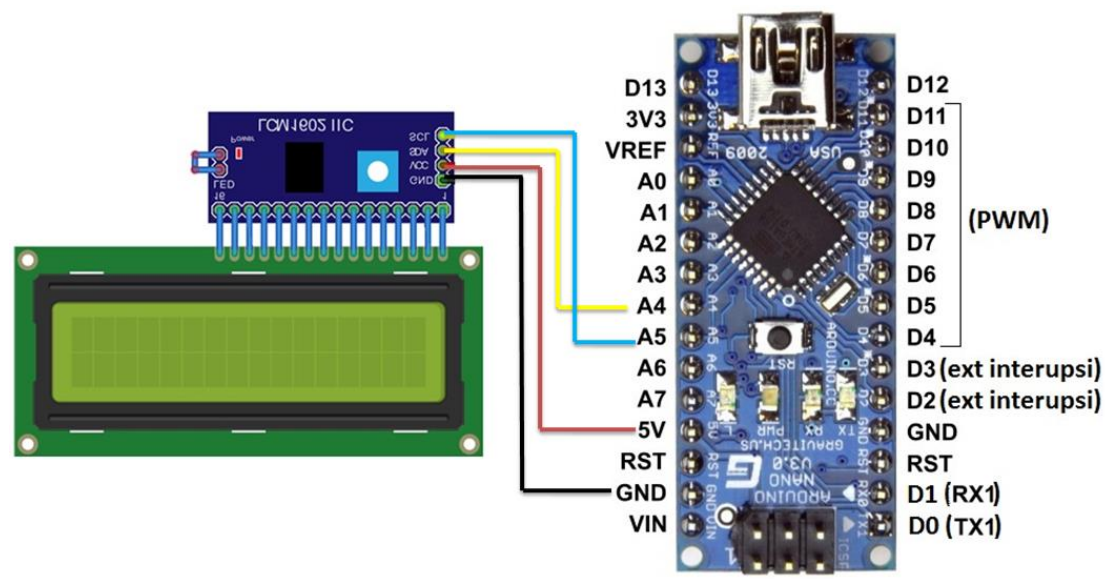

Gambar 2. Konfigurasi Antara LCD 2004 dengan Arduino

Pada gambar 2 LCD di gunakan untuk menampilkan informasi-informasi yang berkaitan dengan pengisian angin ban sepeda motor seperti berapa tekanan angin ban sepeda motor yang akan di berikan, dan tekanan setelah melakukan pengisian angin ban sepeda motor. 
Vol. 1 No. 1, Feb 2021, hlm. 25 - 30

DOI: https://doi.org/10.33330/.v1i1.1019

Available online at http://jurnal.stmikroyal.ac.id/index.php/jutsi

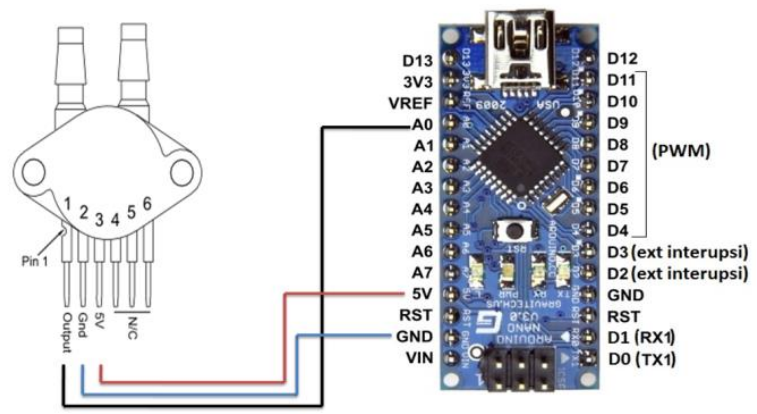

Gambar 3. Konfigurasi MPX5700AP dengan Controller

Pada gambar 3 sensor MPX5700AP di hubungkan ke port analog dari arduino dimana sensor tersebut berfungsi untuk membaca tekanan angin dari ban sepeda motor.

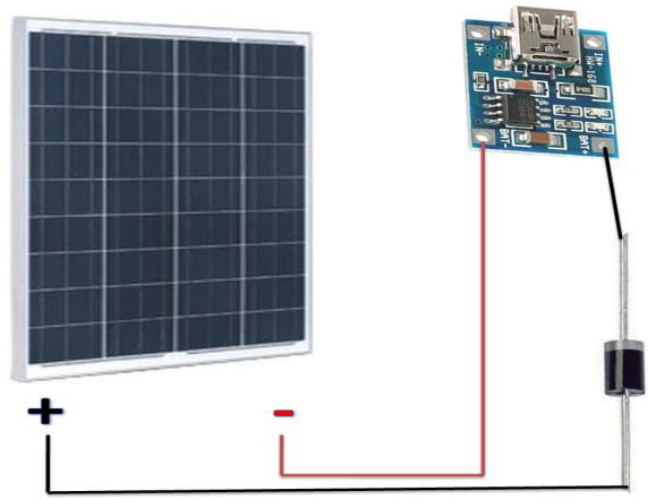

Gambar 4. Konfigurasi Antara Panel Surya dengan IC TP4506

Pada gambar 4 solar cell berfungsi untuk menangkap cahaya matahari dan di simpan ke batrei melalui ICT P4506, dimana energy yang sudah di simpan ke batrei nantinya berfungsi untuk sumber tegangan supaya motor untuk memompa ban sepeda motor bekerja.

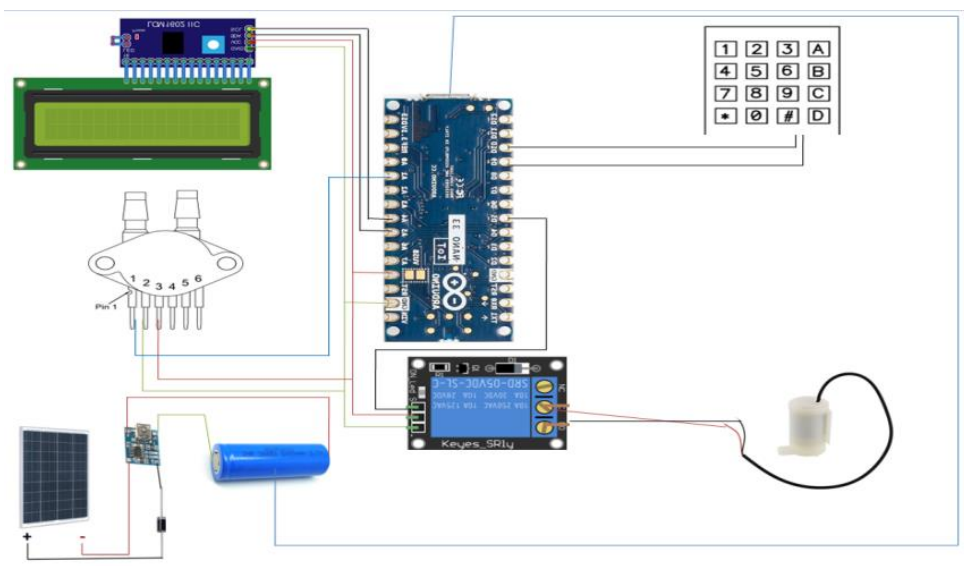

Gambar 5. Rangkaian Keseluruhan Pompa Angin Mini 
Vol. 1 No. 1, Feb 2021, hlm. 25 - 30

DOI: https://doi.org/10.33330/.v1i1.1019

Available online at http://jurnal.stmikroyal.ac.id/index.php/jutsi

Pada gambar 5. dapat dilihat rangkaian keseluruan pompa angin mini yang akan dirancang. PIN pada LCD yang sudah disambungkan dengan I2C sehingga menghemat PIN pada controller, PIN SCL I2C disambungkan ke PIN A5 pada controller, PIN SDA I2C disambungkan ke PIN A4 pada controller, PIN VCC disambungkan ke PIN 5V dan PIN GND pada I2C disambungkan ke PIN GND pada controller. Kemudian pada PIN 9 dan PIN 10 keypad 4x4 disambungkan ke PIN 9 dan PIN 10 pada controller. Sensor MPX5700AP terdapat 6 PIN, namun hanya digunakan 3 PIN, yaitu PIN 3 disambungkan ke PIN 5V pada controller, PIN 2 disambungkan pada GND controller, dan PIN 1 disambungkan ke PIN A1 controller. PIN VCC relay disambungkan ke PIN 5V controller, PIN GND relay disambungkan ke PIN GND controller, dan PIN IN disambungkan ke PIN 2 controller. Panel surya disambungkan ke IC TP4056 dan kemudian disambungkan ke baterai yang kemudian dari baterai disambungkan ke controller yang akan menjadi sumber tegangan untuk mengaktifkan pompa dan controller.

\section{SIMPULAN}

Setelah melakukan perancangan dan pembuatan alat kemudian melakukan pengujian, maka peneliti mengambil simpulan bahwa pengisian baterai melalui panel surya dari mulai dari baterai $0,7 \mathrm{~V}$ sampai dengan penuh $22,2 \mathrm{~V}$ memakan waktu selama lebih kurang 1 jam 51 menit, namun bisa lebih cepat jika matahari lebih terik. Namun jika di charge menggunakan USB melalui IC TP 4506 memakan waktu selama 1 jam 30 menit dan pompa portable yang dirancang menggunakan pompa DC $5 \mathrm{~V}$ hanya bisa menghasilkan tekanan angin maksimal $8 \mathrm{KPA}$, hal ini dikarenakan kontroler jenis arduino hanya bisa menghasilkan delay selama 32.767 milidetik, Untuk menghasilkan tekanan angin 1 KPA membutuhkan waktu sekitar 4 Detik dan berlaku kelipatannya.

\section{DAFTAR PUSTAKA}

[1] D. S. Fane, R. Sutanto, and M. Mara, "Pengaruh Konfigurasi Tabung Kompresor Terhadap Unjuk Kerja Pompa Hidram," Din. Tek. Mesin, vol. 2, no. 2, pp. 62-66, 2012, doi: 10.29303/d.v2i2.95.

[2] M. Samsuri, "Rancang Bangun Alat Bantu Kerja Pengemasan," Ranc. Bangun Alat Bantu Kerja Pengemasan Gas Bio Ke Dalam Tabung Melon, pp. 59-72, 2017.

[3] D. A. Susanto, U. Ayuningtyas, H. Febriansyah, and M. Ayundyahrini, "Evaluasi Instalasi Pompa Air Tenaga Surya Di Indonesia Dengan Menggunakan Standar Iec 62253-2011," J. Stand., vol. 20, no. 2, p. 85, 2018, doi: $10.31153 /$ js.v20i2.687.

[4] Z. Iqtimal and I. Devi, "Aplikasi Sistem Tenaga Surya Sebagai Sumber Tenaga Listrik Pompa Air," J. Karya Ilm. Tek. Elektro, vol. 3, no. 1, pp. 1-8, 2018.

[5] C. Hermanu, B. Apribowo, T. E. S, and M. Anwar, "Prototype Sistem Pompa Air Tenaga Surya Untuk Meningkatkan Produktivitas Hasil Pertanian," J. Abdimas, vol. 21, no. 2, pp. 97-102, 2017. 
Vol. 1 No. 1, Feb 2021, hlm. 25 - 30

DOI: https://doi.org/10.33330/.v1i1.1019

Available online at http://jurnal.stmikroyal.ac.id/index.php/jutsi

[6] M. Refiyanni, H. Zakia, and T. C. Adek, "Analisis Kendaraan Bermotor Roda Dua Berdasarkan (Bok) Desa Tumpok Ladang Kecamatan Kaway Xvi,” J. Tek. Sipil dan Teknol. Konstr., vol. 2, no. 2, pp. 57-68, 2018, doi: 10.35308/jtsutu.v2i2.351.

[7] M. I. Pasaribu, G. Putra, F. A. Anugerah, and Junaidi, "Mengukur Tekanan Udara Pada Ban Secara Otomatis Dengan Kecepatan Anemometer," J. Teknol., vol. 15, no. December, p. 11, 2018.

[8] Z. Azim, M. Ramdhani, and M. Sarwoko, "Alat Pengukur Tekanan Udara pada Ban Kendaraan Beroda Empat Berbasis Ardiuno," vol. 4, no. 3, pp. 3138-3144, 2017. 